\title{
Hubungan Motivasi Berprestasi, Prilaku Kepemimpinan Kepala Sekolah dan Etos Kerja dengan Kinerja Guru
}

\author{
Cok Agus Ady Putra' ${ }^{1}$, Made Yudana ${ }^{2}$, Nyoman Natajaya ${ }^{3}$ \\ 1,2,3 Managemen Pendidikan, Program Pascasarjana, Universitas Pendidikan Ganesha, Indonesia
}

Keywords:

Motivation

school leadership behaviour; work ethos;

teacher performance

\section{Kata kunci:}

motivasi berprestasi; prilaku kepemimpinan kepala sekolah;

etos kerja;

kinerja guru

\begin{abstract}
This study aimed to determine: (1) the relationship between achievement motivation with teacher performance, (2) the relationship between principal leadership behaviors with teacher performance, (3) the relationship between the performance of the teachers work ethic, (4) simultaneous relationship between achievement motivation, school leadership and work ethic with the performance of. This study was designed with a correlational design ex-post facto by using a quantitative approach.The study population was all teachers in SMA N 1 Kubutambahan. The sample retrieval technique using census study with the number 47 . Data were collected by questionnaires. Data were analyzed by multiple regression and partial analysis. The results showed that: (1) there is a significant contribution to the achievement motivation with teacher, (2) there is a significant contribution between principal leadership behaviors with teacher performance, (3) there is a significant contribution to the work ethos of teacher performance, (4) there is a significant contribution between achievement motivation, school leadership behavior, and work ethos simultaneously with the performance of teachers.
\end{abstract}

Abstrak:Penelitian ini bertujuan untuk mengetahui: (1) hubungan antara motivasi berprestasi dengan kinerja guru, (2) hubungan antara perilaku kepemimpinan kepala sekolah dengan kinerja guru, (3) hubungan antara etos kerja dengan kinerja guru, (4) hubungan secara simultan antara motivasi berprestasi, kepemimpinan kepala sekolah dan etos kerja dengan kinerja guru. Penelitian ini dirancang dengan desain korelasional ex-post facto dengan menggunakan pendekatan kuantitatif.. Populasi penelitian ini adalah semua guru di SMA N 1 Kubutambahan. Teknik pengambilan sumpel menggunakan sensus studi dengan jumlah 47 orang. Data dikumpulkan dengan kuesioner. Data dianalisis dengan regresi ganda dan analisis parsial. Hasil penelitian menunjukkan bahwa: (1) terdapat kontribusi yang signifikan antara motivasi berprestasi, (2) terdapat kontribusi yang signifikan antara perilaku kepemimpinan kepala sekolah dengan kinerja guru, (3) terdapat kontribusi yang signifikan antara etos kerja dengan kinerja guru, (4) terdapat kontribusi yang signifikan antara motivasi berprestasi, perilaku kepemimpinan kepala sekolah, dan etos kerja secara simultan dengan kinerja.

\footnotetext{
Alamat Korespondensi:

E-mail: agy.putra @pasca.undiksha.ac.id (Cok Agus Ady Putra)
} 


\section{Pendahuluan}

Pendidikan adalah usaha sadar yang dengan sengaja dirancangkan untuk mencapai tujuan yang telah ditetapkan.Pendidikan bertujuan untuk meningkatkan kualitas sumber daya manusia. Salah satu usaha untuk meningkatkan kualitas sumber daya manusia ialah melalui proses pembelajaran di sekolah. Dalam usaha meningkatkan kualitas sumber daya pendidikan, guru merupakan komponen sumber daya manusia yang harus dibina dan dikembangkan terus-menerus.Pembentukan profesi guru dilaksanakan melalui program pendidikan pra-jabatan maupun program dalam jabatan.Tidak semua guru yang dididik di lembaga pendidikan terlatih dengan baik dan kualified.Potensi sumber daya guru itu perlu terus bertumbuh dan berkembang agar dapat melakukan fungsinya secara potensial.Selain itu pengaruh perubahan yang serba cepat mendorong guru-guru untuk terus-menerus belajar menyesuaikan diri dengan perkembangan ilmu pengetahuan dan teknologi serta mobilitas masyarakat.

Guru merupakan faktor yang sangat dominan dan paling penting dalam pendidikan formal pada umumnya karena bagi siswa guru sering dijadikan tokoh teladan bahkan menjadi tokoh identifikasi diri. Di sekolah guru merupakan unsur yang sangat mempengaruhi tercapainya tujuan pendidikan selain unsur murid dan fasilitas lainnya.Keberhasilan penyelenggaraan pendidikan sangat ditentukan kesiapan guru dalam mempersiapkan peserta didiknya melalui kegiatan belajar mengajar.Namun demikian posisi strategis guru untuk meningkatkan mutu hasil pendidikan sangat dipengaruhi oleh kemampuan profesional guru dan mutu kinerjanya.

Guru merupakan ujung tombak pendidikan sebab secara langsung berupaya mempengaruhi, membina dan mengembangkan peserta didik, sebagai ujung tombak, guru dituntut untuk memiliki kemampuan dasar yang diperlukan sebagai pendidik, pembimbing dan pengajar dan kemampuan tersebut tercermin pada kompetensi guru. Berkualitas tidaknya proses pendidikan sangat tergantung pada kreativitas dan inovasi yang dimiliki guru. Gunawan (1996) mengemukakan bahwa Guru merupakan perencana, pelaksana sekaligus sebagai evaluator pembelajaran di kelas, maka peserta didik merupakan subjek yang terlibat langsung dalam proses untuk mencapai tujuan pendidikan.

Kehadiran guru dalam proses pembelajaran di sekolah masih tetap memegang peranan yang penting. Peran tersebut belum dapat diganti dan diambil alih oleh apapun. Hal ini disebabkan karena masih banyak unsur-unsur manusiawi yang tidak dapat diganti oleh unsur lain. Guru merupakan faktor yang sangat dominan dan paling penting dalam pendidikan formal pada umumnya karena bagi siswa guru sering dijadikan tokoh teladan bahkan menjadi tokoh identifikasi diri. (Wijaya dan Rusyan, 1994).

Guru dituntut memiliki kinerja yang mampu memberikan dan merealisasikan harapan dan keinginan semua pihak terutama masyarakat umum yang telah mempercayai sekolah dan guru dalam membina anak didik. Dalam meraih mutu pendidikan yang baik sangat dipengaruhi oleh kinerja guru dalam melaksanakan tugasnya sehingga kinerja guru menjadi tuntutan penting untuk mencapai keberhasilan pendidikan.Secara umum mutu pendidikan yang baik menjadi tolok ukur bagi keberhasilan kinerja yang ditunjukkan guru.

Faustino Cardosa Gomes (dalam Tresnabudi, 2009:38) mengemukakan definisi kinerja guru sebagai: "Ungkapan seperti output, efisiensi serta efektivitas sering dihubungkan dengan produktivitas". Selanjutnya, definisi kinerja guru menurut A.A. Anwar Prabu Mangkunegara (dalam Tresnabudi, 2009:38) bahwa "Kinerja guru (prestasi kerja) adalah hasil kerja secara kualitas dan kuantitas yang dicapai oleh seorang guru dalam melaksanakan tugasnya sesuai dengan tanggung jawab yang diberikan kepadanya".

Dari sisi lain istilah kinerja diartikan sama dengan unjuk kerja, performasi kerja, prestasi kerja, pencapaian kerja dan penampilan kerja Sedarmayanti (dalam Tresnabudi, 2009:38). Kinerja adalah tingkat keberhasilan seseorang atau kelompok orang dalam melaksanakan tugas dan tanggung jawabnya serta kemampuan untuk mencapai tujuan dan standar yang telah ditetapkan (Sulistyorini, 2001). Sedangkan ahli lain berpendapat bahwa kinerja merupakan hasil dari fungsi pekerjaan atau kegiatan tertentu yang didalamnya terdiri dari tiga aspek yaitu: Kejelasan tugas atau pekerjaan yang menjadi tanggung jawabnya; Kejelasan hasil yang diharapkan dari suatu pekerjaan atau fungsi. Kejelasan waktu yang diperlukan untuk menyelesikan suatu pekerjaan agar hasil yang diharapkan dapat terwujud (Timpe, 2000).

Namun dalam pengamatan awal yang dilakukan di SMA N 1 Kubutambahan masih terdapat berbagai kendala dalam kinerja guru seperti: 1) Kurangnya disiplin kerja guru dalam kegiatan pembelajaran dikelas pada saat jam pelajaran berlangsung, 2) Hasil belajar siswa yang belum optimal, 3) Masih minimnya prestasi guru di tingkat kabupaten, 4) Kurangnya kordinasi kepala sekolah dengan guru dalam mendelegasikan tugas, 5) Kurangnya kretifitas guru dalam pembelajaran, 6) Kurangnya motivasi dalam mengerjakan tugas dari kepala sekolah. 
Kinerja guru dipengaruhi oleh beberapa faktor yakni faktor internal dan external.Menurut Timpe (dalam Tresnabudi, 2009:41), faktor-faktor kinerja terdiri dari faktor internal dan faktor eksternal.Faktor internal yaitu faktor yang dihubungkan dengan sifat-sifat seseorang.Misalnya, kinerja seseorang baik disebabkan karena mempunyai kemampuan tinggi dan seseorang itu tipe pekerja keras, sedangkan seseorang mempunyai kinerja jelek disebabkan orang tersebut mempunyai kemampuan rendah dan orang tersebut tidak memiliki upaya-upaya untuk memperbaiki kemampuannya.Faktor eksternal yaitu faktor-faktor yang mempengaruhi kinerja seseorang yang berasal dari lingkungan.Seperti perilaku, sikap dan tindakan-tindakan rekan kerja, bawahan atau pimpinan, fasilitas kerja, dan iklim organisasi.

Ngakan Ketut Tresna Budi (2009) melakukan penelitian tentang "Hubungan Perilaku Kepemimpinan Kepala Sekolah, Iklim Kerja Sekolah dan .Semangat Kerja Guru terhadap Kinerja Guru SMA Negeri di Kabupaten Gianyar". Dalam penelitian ini terdapat hubungan yang positif dan signifikan antara perilaku guru tentang perilaku kepala sekolah, iklim kerja sekolah dan semangat kerja guru terhadap kinerja guru SMA N Kabupaten Gianyar dengan kontribusi sebesar 63,0\%.

Ida Bagus Nyoman Japa (2008) melakukan penelitian tentang "Kontribusi Perilaku Kepemimpinan Kepala Sekolah, Iklim Kerja dan Etos Kerja terhadap Kinerja Guru Pembimbing pada SMP Negeri Kabupaten Karangasem". Ada kontribusi secara bersama-sama ketiga variabel dengan kinerja = $78,4 \%$

Dari faktor-faktor tersebut penulis mengambil tiga faktor yang akan diteliti yakni:

Motivasi berasal dan kata latin "mevere" yang berarti dorongan atau menggerakkan (Sukari, 1999: 54). Para ahli psikologi mencoba mendefinisikan motivasi sesuai dengan versinya masing-masing yang berbeda antara yang satu dengan yang lainnya.Perbedaan ini umumnya disebabkan oleh karena perbedaan sudut pandang dan dari hasil pengamatan dan penelitian yang dilakukan.Sedangkan Sukarno (2002:13) mengatakan motivasi merupakan bagian kasat mata yang tercermin dalam perilaku organisasi, yaitu hasrat/kemauan untuk melakukan tingkat upaya yang tinggi kearah tujuan organisasi, dengan demikian motivasi merupakan bagian integral dalam upaya mengoptimalkan pengendalian manajemen suatu organisasi.Sejalan dengan pendapat diatas, Mathis dan Jackson (2001:89) mengatakan bahwa motivasi merupakan hasrat seseorang yang menyebabkan orang tersebut melakukan tindakan.

Kepemimpinan adalah bagian penting manjemen, tetapi tidak sama dengan manajemen. Kepemimpinan merupakan kemampuan yang dipunyai seseorang untuk mempengaruhi orang lain agar bekerja mencapai tujuan dan sasaran. Manajemen mencakup kepemimpinan tetapi juga mencakup fungsifungsi lainnya seperti perencanaan, penorganisasian, pengawasan dan evaluasi. Kepemimpinan atau leadership dalam pengertian umum menunjukkan suatu proses kegiatan dalam hal memimpin, membimbing, mengontrol perilaku, perasaan serta tingkah laku terhadap orang lain yang ada dibawah pengawasannya. Disinilah peranan kepemimpinan berpengaruh besar dalam pembentukan perilaku bawahan.menurut Handoko kepemimpinan merupakan kemampuan seseorang untuk mempengaruhi orang lain agar mencapai tujuan dan sasaran.

Kepemimpinan dapat diartikan sebagai kegiatan untuk mempengaruhi orang-orang yang diarahkan terhadap pencapaian tujuan organisasi (Mulyasa, 2002:107), sedangkan Supardi (dalam Mulyasa, 2002:107) mendefinisikan kepemimpinan sebagai kemampuan untuk mengarahkan, mempengaruhi, memotivasi, mengarahkan, menasehati, membimbing, menyuruh, memerintah, melarang, dan bahkan menghukum (kalau perlu), serta membina dengan maksud agar manusia sebagai media menejemen mau bekerja dalam rangka mencapai tujuan administrasi secara efektif dan sfisien.

Apabila mengintroduksi pendapat Panji Anoraga dan Sri Suryati (1995:75) maka etos kerja diartikan sebagai pandangan dan sikap suatu bangsa atau umat tarhadap kerja.Berpijak pada pengertian bahwa etos kerja menggambarkan suatu sikap, maka dapat ditegaskan bahwa etos kerja mengandung makna sebagai aspek evaluatif yang dimiliki oleh individu atau kelompok dalam memberikan penilaian terhadap kegiatan kerja.Mengingat kandungan yang ada dalam pengertian etos kerja adalah unsur penilaian, maka secara garis besar dapat digolongkan menjadi dua, yaitu penilaian positif dan negative.

Etos kerja yang dimiliki oleh seseorang atau kelompok masyarakat akan menjadi sumber motivasi bagi perbuatannya. Apabila dikaitkan dengan situasi kehidupan manusia yang sedang "membangun", maka etos kerja yang tinggi akan dijadikan sebagai prasyarat yang mutlak yang harus ditumbuhkan dalam kehidupannya. Karena hal itu akan membuka pandangan dan sikap kepada manusianya untuk menilai tinggi terhadap kerja keras dan sungguh-sungguh, sehingga dapat mengikis sikap kerja yang asal-asalan, tidak berorientasi terhadap mutu, atau kualitas yang semestinya.

Berdasarkan latar belakang, faktor-faktor penelitian yang mempengaruhi kinerja guru maka pada kesempatan ini akan dilakukan penelitian untuk mengetahui hubungan motivasi berprestasi, perilaku kepemimpinan kepala sekolah, dan etos kerja dengan kinerja guru SMA N 1 Kubutambahan.

Dari berbagai masalah yang berkaitan dengan kinerja guru, peneliti membatasi permasalahan yang diteliti agar memperoleh hasil yang akurat. Adapun permasalahan yang diteliti sebagai berikut :. 
(1)Apakah terdapat hubungan antara motivasi berprestasi dengan kinerja guru di SMA N 1 Kubutambahan?; (2)Apakah terdapat hubungan antara perilaku kepemimpinan kepala sekolah dengan kinerja guru di SMA N 1 Kubutambahan?; (3)Apakah terdapat hubungan antara etos kerja dengan kinerja guru di SMA N 1 Kubutambahan? (4)Secara simultan apakah terdapat hubungan antara motivasi berprestasi, kepemimpinan kepala sekolah dan etos kerja dengan kinerja guru di SMA N 1 Kubutambahan?

\section{Metode}

Rancangan penelitian yang digunakan adalah ex post facto.Metode survei dirancang untuk memperoleh informasi tentang status gejala pada saat penelitian dilakukan dengan tujuan untuk melukiskan variabel atau kondisi yang ada dalam suatu situasi. (Tresnabudi, 2009:59).Populasi berarti pula totalitas semua nilai-nilai yang mungkin hasil menghitung ataupun pengukuran jumlah dan pada karakteristik tertentu mengenai sekumpulan objek yang lengkap dan jelas (Sudjana, 1992:6).Dengan demikian yang termasuk populasi subjek dalam penelitian ini adalah seluruh guru SMA Negeri I Kubutambahan.Tehnik pengambilan sampel dalam penelitian ini menggunakan sensus studi dengan jumlah 47 orang.

Variabel bebas dalam penelitian ini adalah, motivasi berprestasi(X1), perilaku kepemimpinan kepala sekolah (X2) dan etos kerja guru, (X3). Adapun variabel terikatnya adalah kinerja guru SMA (Y). Instrumen utama dalam penelitian ini adalah kuesioner: (1) kuesioner tentang motivasi berprestasi, (2) kuesioner tentang perilaku kepemimpinan kepala sekolah, (3) kuesioner tentang etos kerja guru, dan (4) APKG. Dalam penyusunan instrumen terlebih dahulu dibuat kisi-kisi instrument,dan telah diuji validitas dan reabilitasnya.

Data yang diperoleh dari penelitian.dideskripsikan menurut masing-masing variabel, yaitu Motivasi berprestasi, prilaku kepemimpinan kepala sekolah, etos kerja, dan Kinerja Guru. Kemudian akan dicari harga rata-rata (M), standar deviasi (SD), modus (Mo), dan median (Me) setiap variabel yang diteliti. Untuk mendapatkan harga-harga tersebut diperlukan tabel distribusi frekuensi dan histogram untuk setiap variabel penelitian. Tabel tersebut dibuat dengan cara membuat kelas interval dengan aturan Sturges (Sugiyono, 2006). Kemudian dilanjutkan dengan menggunakan regresi ganda dan korelasi parsial.

\section{Hasil dan Pembahasan}

Untuk mendapatkan gambaran mengenai karakteristik distribusi skor dari masing-masing variable, berikut disajikan skor tertinggi, sekor terendah, harga rerata, simpangan baku varian median, modus, histogram dan kategori masing-masing variable yang diteliti. Untuk memudahkan mendirkripsikan masing-masing variable, dibawah ini disajikan rangkuman stastistik deskriptif seperti pada tabel 1 di bawah ini.

Tabel 1 Rangkuman Statistik dari Variabel Motivasi Berprestasi, Perilaku Kepemimpinan Kepala Sekolah, Etos Kerja dan Kinerja Guru

\begin{tabular}{ccccc}
\hline $\begin{array}{c}\text { Variabel } \\
\text { Statistik }\end{array}$ & $\mathbf{X}_{\mathbf{1}}$ & $\mathbf{X}_{\mathbf{2}}$ & $\mathbf{X}_{\mathbf{3}}$ & $\mathbf{Y}$ \\
\hline Rata-Rata & 108,68 & 108,38 & 111,74 & 168,34 \\
Median & 110 & 110 & 112 & 170 \\
Modus & 110 & 107 & 115 & 170 \\
Setandar Deviasi & 8,34 & 9,15 & 7,10 & 8,35 \\
Varian & 69,53 & 83,76 & 50,41 & 69,79 \\
Rentangan & 32 & 35 & 30 & 30 \\
Max & 122 & 125 & 125 & 185 \\
Min & 90 & 90 & 95 & 155 \\
\hline
\end{tabular}

Keterangan:

X1 : Motivasi Berprestasi

X2 : Perilaku Kepemimpinan Kepala Sekolah

X3 : Etos Kerja

Y : Kinerja Guru 
Hasil analisis ditemukan: (1) motivasi berprestasi guru termasuk kategori baik, perilaku kepemimpinan kepala sekolah termasuk kategori baik, etos kerja guru termasuk kategori baik, dan kinerja guru SMA N 1 Kubutambahan termasuk kategori baik; (2) terdapat kontribusi yang signifikan antara motivasi berprestasi dengan kinerja guru SMA N1 Kubutambahan melalui persamaan regresi $\hat{Y}=95,582+$ 0,669X1 dengan kontribusi sebesar 44,6\% dan sumbangan efektif sebesar 18,26\%; (3) terdapat kontribusi yang signifikan antara perilaku kepemimpinan kepala sekolah dengan kinerja guru SMA N 1 Kubutambahan melalui persamaan regresi $\hat{Y}=91,918+0,705 X 2$ dengan kontribusi sebesar 59,7\% dan sumbangan efektif sebesar 35,95\%; (4) terdapat kontribusi yang signifikan antara etos kerja dengan kinerja guru SMA N 1 Kubutambahan melalui persamaan regresi $\hat{Y}=83,236+0,762 X 3$ dengan kontribusi sebesar 41,9\% dan sumbangan efektif sebesar 18,07\%; dan (5) terdapat kontribusi yang signifikan antara motivasi berprestasi, perilaku kepemimpinan kepala sekolah, dan etos kerja secara simultan dengan kinerja guru SMAN I Kubutambahan. melalui persamaan regresi $\hat{Y}=55,794+0,274 X 1+0,425 X 2+$ 0,328X3 dengan kontribusi sebesar 72,3\%.

Korelasi parsial yang digunakan adalah korelasi parsial jenjang kedua.Hal ini dimaksudkan untuk mengetahui kontribusi satu variabel bebas dengan variabel terikat dengan mengendalikan variabel bebas lainnya. Dengan bantuan program SPSS 16 for windows diperoleh besarnya koefisien korelasi parsial r1y$23=0,668 ; \mathrm{r} 2 \mathrm{y}-13=0,772 ; \mathrm{r} 3 \mathrm{y}-12=0,647$ Hasil perhitungan dan pengujian disajikan pada tabel 2 berikut.

Tabel 2. Uji Signifikansi Koefisien Korelasi Parsial Variabel Motivasi Berprestasi (X $\left.\mathrm{X}_{1}\right)$, Perilaku Kepemimpinan Kepala Sekolah $\left(\mathrm{X}_{2}\right)$ dan Etos Kerja $\left(\mathrm{X}_{3}\right)$ secara bersama-sama dengan Kinerja Guru (Y)

\begin{tabular}{|c|c|c|c|c|c|c|}
\hline \multirow{2}{*}{$\begin{array}{l}\text { Korelasi } \\
\text { Parsial }\end{array}$} & \multirow{2}{*}{$\begin{array}{l}\text { Koef. } \\
\text { Korelasi }\end{array}$} & \multirow[t]{2}{*}{$t_{\text {hitung }}$} & \multicolumn{2}{|c|}{$t_{\text {tabel }}$} & \multirow{2}{*}{$\begin{array}{l}\mathrm{dk}(\mathrm{N}- \\
\mathrm{m}-1)\end{array}$} & \multirow{2}{*}{ Keterangan } \\
\hline & & & $\alpha=0,05$ & $\alpha=0,01$ & & \\
\hline$r_{1 y-23}$ & 0,668 & 2,718 & 2,000 & 2,666 & 46 & Signifikan \\
\hline$r_{2 y-13}$ & 0,772 & 4,387 & 2,000 & 2,666 & 46 & Signifikan \\
\hline$r_{3 y-12}$ & 0,647 & 2,891 & 2,000 & 2,666 & 46 & Signifikan \\
\hline
\end{tabular}

r1y-23 : Kontribusi Variabel Motivasi Berprestasi terhadap kinerja guru

dengan mengendalikan variabel perilaku kepemimpinan kepala sekolah dan etos kerja.

r2y-13 : Kontribusi Variabel perilaku kepemimpinan kepala sekolah terhadap kinerja guru dengan mengendalikan variabel motivasi berprestasi dan etos kerja.

r3y-12 : Kontribusi Variabel etos kerja terhadap kinerja guru dengan mengendalikan variabel motivasi berprestasi dan perilaku kepemimpinan kepala sekolah.

Data motivasi yang diperoleh dari hasil pengukuran terhadap responden menunjukan bahwa skor tertinggi yang dicapai adalah 122 dari skor tertinggi yang mungkin dicapai yaitu 150, sedangkan skor terendah yang dicapai adalah 90 dari skor terendah yang mungkin dicapai yaitu 30. Dari hasil perhitungan tendensi sentral diperoleh harga rata-rata sebesar 108,68 simpangan baku sebesar 8,34 varian sebesar 69,53 modus 110 dan median 110. Hasil perhitungan menunjukkan bahwa kecenderungan motivasi berprestasi guru SMA N 1 Kubutambahan dapat dikatakan baik.

Hasil analisis juga menunjukkan bahwa motivasi berprestasi member kontribusi dan signifikan terhadap kinerja guru SMA N 1 Kubutambahan Temuan ini mengimplikasikan bahwa dalam usaha meningkatkan kinerja guru, kepala sekolah sebagai pemimpin sekolah harus mampu membangkitkan dan mengembangkan motivasi berprestasi guru melalui latihan-latihan. McClelland mengatakan bahwa motivasi berprestasi bukan potensi bawaan, sehingga besar kemungkinannya potensi tersebut untuk dikembangkan melalui latihan-latihan. Semakin tinggi motivasi berprestasi guru, semakin tinggi pula kinerjanya.Demikian sebaliknya, semakin rendah motivasi berprestasi guru menyebabkan semakin menurun kinerjanya.

Hasil penelitian ini didukung oleh hasil penelitian yang dilakukan sebelumnya. Arya Putra, I Gede melakukan penelitian terhadap guru-guru SMK Negeri 3 Singaraja pada tahun 2005. Beliau meneliti tentang kontribusi perilaku kepemimpinan kepada sekolah, iklim kerja sekolah, dan motivasi berprestasi terhadap kinerja guru.Dari hasil penelitiannya ditemukan bahwa motivasi berprestasi guru memberi kontribusi yang siginifikan terhadap kinerja guru dengan kontribusi efektif sebesar 36,399\% dan kontribusi relatife sebesar 69,215\%.

Berdasarkan hasil temuan di atas, bahwa ada kolerasi serta kontribusi yang positif dan signifikan antara motivasi berprestasi guru terhadap kinerja guru.Semakin tingi motivasi berprestasi guru, semakin tinggi pula kinerjannya.Begitu pula sebaliknya. Implikasinya dalam duniai pendidikan, bahwa kepala 
sekolah selaku top leader di sekolah harus mampu menciptakan kondisi yang mampu menumbuhkan motivasi berprestasi guru agar kinerjanya meningkat. Dengan demikian dapat dikatakan motivasi berprestasi guru di SMA N 1 Kubutambahan merupakan faktor penting dalam penigkatan mutu pendidikan.

Data perilaku kepemimpinan kepala sekolah yang diperoleh dari hasil penelitian pengukuran terhadap responden menunjukkan bahwa skor tertinggi yang dicapai responden adalah 125 dari sekor tertinggi yang mungkin dicapai yaitu 150 sedangkan skor terendah yang dicapai responden adalah 90 dari skor terendah yang mungkin dicapai yaitu 30. Dari hasil perhitungan tendensi sentral diperoleh harga rata-rata sebesar 108,38 simpangan baku sebesar 9,15 varian sebesar 83,76 modus 107 dan median 110. Hasil perhitungan menunjukkan bahwa kecenderungan perilaku kepemimpinan kepala sekolah SMA N 1 Kubutambahan dapat dikatakan baik.

Hasil penelitian ini didukung oleh hasil penelitian yang dilakukan sebelumnya.Ngakan Ketut Tresna Budi (2009) melakukan penelitian tentang "Hubungan Perilaku Kepemimpinan Kepala Sekolah, Iklim Kerja Sekolah dan .Semangat Kerja Guru terhadap Kinerja Guru SMA Negeri di Kabupaten Gianyar". Dari hasil penelitiannya ditemukan bahwa perilaku kepemimpinan kepala sekolah memberi kontribusi yang siginifikan terhadap kinerja guru sebesar $45,5 \%$.

Sebagai mana deskripsi data hasil penelitian, data perilaku kepemimpinan kepala sekolah menunjukkan kecendrungan skor baik.Kepemimpinan kepala sekolah merupakan salah satu faktor yang dapat mendorong untuk dapat mewujudkan visi, misi, tujuan dan sasaran sekolah melalui programprogram yang dilaksanakan secara terencana dan bertahap. Kepala sekolah adalah orang yang bertanggung jawab akan jalannya sekolah sebagai institusi pendidikan. Sebagai institusi atau organisasi pendidikan, kepemimpinan kepala sekolah dan menejemennya sangat mempengaruhi dalam pencapaian tujuan sekolah.Demikian juga sebagai organisasi, sekolah memerlukan tidak hanya seorang pemimpin yang mengelola administrasi, atau mengelola persoalan keuangan saja tetapi lebih jauh dari itu sekolah memerlukan seorang pemimpin yang mampu mengelola segala sumberdaya sekolah. Sumberdaya sekolah atau sumberdaya pendidikan meliputi: manusia, sarana dan prasarana, biaya teknologi dan informasi. SDM merupakan sumberdaya yang paling penting dalam organisasi, yang menurut Sheety dan Bucher (dalam Tresnabudi,2009:14) mengandung aspek-aspek seperti: kompetensi, ketrampilan, kemampuan, sikap, perilaku, motivasi dan komitmen

Dari urain di atas, maka dapat dikatakan kepala sekolah memegang peran sentral dalam menghimpun, memanfaatkan dan menggerakan secara optimal seluruh potensi dan sumberdaya yang terbatas untuk membawa sekolah dan masyarakat sekolah yang dikelolanya untuk mencapai tujuan yang telah ditetapkan.Data etos kerja yang diperoleh dari hasil pengukuran terhadap responden menunjukan bahwa skor tertinggi yang dicapai responden adalah 125 dari skor tertinggi yang mungkin dicapai yaitu 150, sedangkan skor terendah yang dicapai adalah 95 dari skor terendah yang mungkin dicapai yaitu 30. Dari hasil perhitungan tendensi sentral diperoleh harga rata-rata sebesar 111,74 simpangan baku sebesar 7,10 varian sebesar 50,41 modus 115 dan median 112. Hasil perhitungan menunjukkan bahwa kecenderungan etos kerja guru SMA N 1 Kubutambahan dapat dikatakan baik.

Temuan seperti yang dipaparkan di atas mengisyaratkan bahwa etos kerja berkontribusi secara signifikan terhadap kinerja guru. Hal ini karena etos kerja pada intinya adalah suatu sikap guru terhadap kerja yang dicirikan oleh adanya bekerja tulus penuh syukur, bekerja penuh tanggung jawab, kerja tuntas penuh integritas, bekerja keras penuh semangat, bekerja serius penuh kecintaan, bekerja kreatif penuh suka cita, bekerja tekun penuh keunggulan, bekerja sempurna penuh kerendahan hati. Apabila seseorang memiliki ciri-ciri seperti tersebut diatas, hal ini akan berdampak pada kinerjanya.

Hasil penelitian ini juga didukung oleh penelitian terdahulu yakni Sumawa (2009) melakukan penilitian yang berjudul "Kontribusi Intensitas Keterlibatan Guru dalam Kegiatan MGMP, Tingkat Pendidikan, dan Etos Kerja terhadap Kinerja Guru SMP Negeri di Kecamatan Baturiti". Dalam penelitian ini ditemukan kolerasi postif yang signifikan antara etos kerja guru dengan kinerja guru sebesar 0,502 $(\mathrm{p}<0,05)$ dengan kontribusi sebesar $25,20 \%$ dan sumbangan efektif sebesar $14,80 \%$.

Sinamon (2009:33) menyatakan bahwa etos kerja adalah seperangkat perilaku kerja postif yang berakar pada kesadaran kental, keyakinan yang fundamental, disertai komitmen yang total pada paradigma kerja yang integral. Istilah paradigma di sini berarti konsep utama tetang kerja itu sendiri yang mencakup idealisme yang mendasari, prinsip-prinsip yang mengatur, nilai-nilai yang menggerakkan, sikap-sikap yang dilahirkan, standar-standar yang hendak dicapai. Jika seseorang, suatu organisasi atau suatu komunitas menganut paradigma kerja tertentu, percaya padanya secara tulus, serta berkomitmen pada paradigma kerja tersebut maka kepercayaan tersebut akan melahirkan sikap kerja dan perilaku kerja secara khas. Itulah etos kerja mereka, dan itu pula budaya kerja mereka.Etos kerja merupakan sikap terhadap kerja sehingga dalam diri seseorang atau sekelompok orang dalam organisasi menyikapi 
paradigma kerja menjadi berbeda ada yang positif, ada yang negatif, ada yang tinggi ada yang rendah, sehingga timbullah contoh etos kerja rendah, dan seterusnya.

\section{Simpulan}

Berdasarkan analisis dan pembahasan yang diuraikan pada bagian sebelumnya ditemukan halhal sebagai berikut.

1) Terdapat kontribusi yang signifikan antara motivasi berprestasi dengan kinerja guru SMA N1 Kubutambahan melalui persamaan regresi $\hat{Y}=95,582+0,669 X 1(p<0,05)$ dengan kontribusi sebesar 44,6\% dan sumbangan efektif sebesar $18,26 \%$.

2) Terdapat kontribusi yang signifikan antara perilaku kepemimpinan kepala sekolah dengan kinerja guru SMA N 1 Kubutambahan melalui persamaan regresi $\hat{Y}=91,918+0,705 X 2(p<0,05)$ dengan kontribusi sebesar $59,7 \%$ dan sumbangan efektif sebesar 35,95\%.

3) Terdapat kontribusi yang signifikan antara etos kerja dengan kinerja guru SMA N 1 Kubutambahan melalui persamaan regresi $\hat{Y}=83,236+0,762 X 3(p<0,05)$ dengan kontribusi sebesar $41,9 \%$ dan sumbangan efektif sebesar $18,07 \%$.

4) Terdapat kontribusi yang signifikan antara motivasi berprestasi, perilaku kepemimpinan kepala sekolah, dan etos kerja secara simultan dengan kinerja guru SMAN I Kubutambahan. melalui persamaan regresi $\hat{Y}=55,794+0,274 X 1+0,425 X 2+0,328 X 3(p<0,05)$ dengan kontribusi sebesar $72,3 \%$.

Berdasarkan temuan tersebut dapat disimpulkan bahwa sebelum dan sesudah diadakan pengendalian motivasi berprestasi, perilaku kepemimpinan kepala sekolah,dan etos kerja berkontribusi terhadap kinerja guru SMA N 1 Kubutambahan.

\section{Referensi}

Arya Putra, I Gede. (2005). Kontribusi Perilaku Kepemimpinan Kepada Sekolah, Iklim Kerja Sekolah, dan Motivasi Berprestasi terhadap Kinerja Guru SMK Negeri 3 Singaraja. Singaraja: Tesis ini tidak diterbitkan.

Gunawan, Ary H. (1996). Administrasi Sekolah Administrasi Mikro. Jakarta: Rineka Cipta.

Mathis, Robert L \& Jackson Jhon H. 2001. Manajemen Sumber Daya Manusia. Buku 1. Jakarta: Salemba Empat.

Mulyasa, E. (2002). Manajemen Berbasis Sekolah. Bandung: PT. Remaja Rosdakarya.

Panji Anoraga dan Sri Suryati.(1995). Prilaku Keorganisasian. Jakarta: Pustaka Jaya.

Sukari.(1999). Studi Korelasional Antara Persepsi Widyaiswara Terhadap Jabatannya Dan Motivasi Berperstasi Deengan Kinerja Widyaiswara.jurnal teknologi dan pendidikan Volume 1, Nomor 1.

Sukarno.(1992). Dasar-DasarManajemen.Jakarta : Miswar.

Sulistyorini.(2001). Pengaruh Motivasi Terhadap Tingkat Efektivitas Kerja Dosen STAIN Malang. Universitas Negeri Malang: Tesis tidak diterbitkan.

Sumawa, I Wayan.(2009). "Kontribusi Intensitas Keterlibatan Guru pada kegiatan MGMP, Tingkat Pendidikan, dan Etos Kerja terhadap Kinerja Guru SMP Negeri di Kecamatan Batiriti". Singaraja.Tesis tidak diterbitkan.

Timpe, A.D (2000). Memimpin Manusia Seri Manajemen Sumber Daya Manusia (Edisi Bahasa Indonesia). Jakarta: Gramedia.

Tresnabudi.(2009). Hubungan Prilaku Kepemimpinan, Iklim Kerja Sekolah, Semangat Kerja Guru terhadap Kinerja Guru. Singaraja: Tesis tidak diterbitkan.

Wijaya, cece dan Tabrani Rusyan.(1994). Kemampuan Dasar Guru dalam Proses Belajar Mengajar. Bandung: PT. Remaja Rosdakarya. 